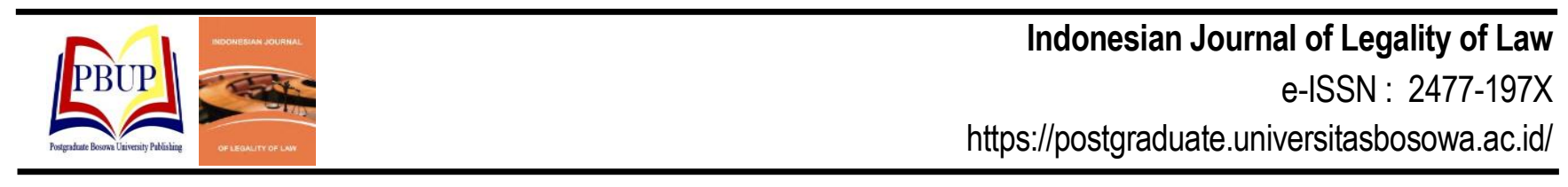

\title{
FUNGSI PENGAWASAN OMBUDSMAN TERHADAP PELAKSANAAN TATA KELOLA ADMINISTRASI DI PENGADILAN NEGERI MAMUJU
}

\author{
Ombudsman Supervision Fungction of Implementationof of Administrative Governance In Court of \\ Mamuju
}

\author{
Muh. Arifain ${ }^{1}$, Abdul Salam Siku ${ }^{1}$, Abd. Haris Hamid ${ }^{1}$ \\ ${ }^{1}$ Program Studi Ilmu Hukum Program Pascasarjana Universitas Bosowa \\ Email: amlasape@gmail.com
}

Diterima: 01 April 2020/Disetujui: 05 Juni 2020

\begin{abstract}
ABSTRAK
Tujuan penelitian ini adalah untuk mengetahui efektifitas fungsi pengawasan ombudsman terhadap pelaksanaan tata kelola administrasi di Pengadilan Negeri Mamuju serta untuk mengetahui apa saja kendala yang menjadi kendala dalam menjalankan fungsi pengawasan Ombudsman terhadap tata kelola administrasi di Pengadilan Negeri Mamuju, Penelitian ini dilakukan di Ombudsman Republik Indonesia Perwakilan Sulawesi Barat dan di Pengadilan Negeri Mamuju. Metode penelitian yang digunakan adalah penelitian kualitatif yaitu penelitian yang bertujuan menjelaskan fenomena dengan melalui pengumpulan data dengan pendekatan yuridis normatif dan yuridis empiris. Maksudnya pendekatan yang dilakukan untuk menganalisa tentang fungsi pengawasan Ombudsman terhadap pelaksanaan tata kelola administrasi Pengadilan Negeri Mamuju. Hasil penelitian ini menunjukkan bahwa fungsi Pencegahan dan Pemeriksaan Laporan Oleh Ombudsman terhadap pelaksaaan Tata Kelola Administrasi Pengadilan Negeri mamuju kurang efektif, sedangkan penerimaan dan verifikasi laporan cukup efektif namun secara umum Ombudsman Perwakilan Sulawesi Barat cukup efektif namun dalam pelaksanaannya terdapat beberapa kendala yaitu kendala mengenai Regulasi, Sumber Daya Manusia, Anggaran dan factor Sosialisasai terhadap Masyarakat.
\end{abstract}

Kata Kunci : Pengawasan, Ombudsman, Tata Kelola Administrasi, Pengadilan Negeri, Mamuju

\section{ABSTRACT}

The purpose of this study is to determine the effectiveness of the ombudsman oversight function on the implementation of administrative governance in the Mamuju District Court and to find out the problems that become obstacles in carrying out the Ombudsman's supervision function of administrative governance in the Mamuju District Court. This research was conducted at the Ombudsman Republic of Indonesia Representative in West Sulawesi and in the Mamuju District Court. The research method used is qualitative research, which is research that aims to explain the phenomenon by collecting data through normative and juridical approaches. That is the approach taken to analyze the Ombudsman's oversight function of the administration of the Mamuju District Court administration. The results of this study indicate that the function of the Prevention and Examination of Reports by the Ombudsman on the implementation of the District Court Administration is less effective, while receiving and verifying reports are quite effective but in general the West Sulawesi Representative Ombudsman is quite effective although in its implementation there are several obstacles namely the constraints regarding Regulation, Human Resources, Budget and Socialization factors towards the Community.

Keywords: Oversight, Ombudsman, Administrative Administration, District Court, Mamuju

\section{PENDAhUluAN}

Negara-negara modern di dunia saat ini mengklaim sebagai negara hukum. Secara konseptual negara hukum adalah negara yang dalam penyelenggaraan pemerintahan dan kehidupan masyarakatnya berdasarkan aturan hukum. Oleh karena itu negara hukum merupakan perlawanan dari negara kekuasaan. Secara teoritis menurut Mochtar Kusumaatmaja dalam Irfan Fachrudin mangatakan "pengertian mendasar dari "negara hukum" adalah kekuasaan tumbuh pada hukum dan semua orang tunduk kepada hukum" (Fachrudin, 2004).

Indonesia adalah Negara Demokrasi yang berdasarkan hukum yang menjungjung tinggi kedaulatan rakyat, Sehingga Pemerintah harusnya menjamin hak-hak setiap warga negaranya, perlindungan dan pelayanan hukum merupakan hak setiap warga Negara, dari harapan tersebut sehingga Negara membentuk lembaga Negara yang berwenang dalam pengawasan pelayanan publik oleh institusi pelayanan publik. 
Lahirnya Undang-undang No. 37 Tahun 2008 diharapkan masyarakat dapat mendapatkan pelayanan publik yang memadai serta sesuai dengan harpan, sehingga maladministrasi dapat diminimalisir serta pencegahan tindak pidana korupsi dapat di cegah melalui pelaksanaan tata kelola administrasi yang baik. Ombudsman Republik Indonesia berwenang mengawasi seluruh penyelenggara publik yang mana sebagain atau seluruh dananya bersumbar dari APBD maupun APBN, dalam melaksanakan tugas dan wewenangnya Ombudsman Republik Indonesia harus mandiri dan independen. Hingga saat ini Ombudsman Republik Indonesia telah membentuk Ombudsman Perwakilan di setiap Provinsi seluruh Indonesia untuk memaksimalkan fungsi pengawasannya di tingkat daerah. Untuk mencapai tujuannya (mewujudkan good governance) Ombudsman di Indonesia bertugas antara lain mengupayakan partisipasi masyarakat dengan menciptakan keadaan yang kondusif bagi terwujudnya birokrasi sederhana yang bersih, pelayanan umum yang baik, penyelenggaraan peradilan yang efisien dan professional termasuk proses peradilan yang independen dan fair sehingga dapat dijamin tidak akan ada keberpihakan (Surahman dam Sujata, 2002)

Kehadiran Ombudsman di Provinsi Sulawesi Barat diharapkan mampu mewujudkan penyelenggara peradilan yang bersih, Bebas dari Korupsi, Kolusi dan Nepotisme bersih serta penyalahgunaan kekuasaan dan/atau jabatan, serta dapat membantu masyarakat untuk memperoleh pelayanan publik yang baik, dan professional berdasarkan kepastian hukum, keadilan dan persamaan dari penyelenggara pelayanan publik. Cara kerja Ombudsman meliputi bagaimana dan dengan cara apa Ombudsman menerima laporan masyarakat, proses penelitian administrasi, proses penyusunan resume, penyusunan permintaan klarifikasi sampai dengan keluarnya rekomendasi Ombudsman (Masthuri, 2005). Sebagai pelaksana Penyelenggaraan peradilan tingkat pertama, tentu harapan masyarakat untuk mendapatkan keadilan di serahkan sepenuhnya kepada Pengadilan Negeri. Sebagaimana penegakan hukum yang dijalankan melalui proses peradilan, tentu akan berjalan sesuai ekspektasi hukum itu sendiri apabila proses peradilan dilaksanakan dengan mengikuti tata kelola administrasi yang baik, karena tata kelola administrasi merupakan salah satu factor out put pelayanan lembaga peradilan apakah benar-benar telah menjalankan fungsi sebagaimana mestinya, hal tersebut ditentukan dengan bagaimana kenyataan dalam praktek pada lembaganya.

Proses peradilan yang seharusnya berlangsung sederhana lalu berubah menjadi proses yang sangat rumit, sehingga begitu rumitnya proses beracara di pengadilan sehingga menjadi tidak sederhana. Hal tersebut terjadi bukan disebabkan karena ada masalah pada hukum tetapi justru berubah menjadi masalah proses non hukum yang bukan merupakan bagian dari implementasi hukum itu sendiri,. Persoalan non hukum tersebut merupakan hal yang menjadi faktor utama penyebab ketidakberesan dalam proses beracara atau upaya mencari keadilan di lingkungan lembaga peradilan.

Hal inilah yang menjadi stigma negative masyarakat terhadap penegakan supremasi hukum dan keadilan di Indonesia, semua aktor didalam lembaga peradilan mulai dari hakim, panitera, jaksa, dan polisi terlibat dalam praktik koruptif bahkan juga terjadi di seluruh tingkatan, juga melibatkan pengacara dan masyarakat pencari keadilan itu sendiri. Di kalangan praktisi hukum seolah-olah telah menganggap biasa terhadap praktek judicial corruption. Bahkan dianggap sebagai sesuatu yang memang harus dilakukan, atau terpaksa harus dilakukan. namun praktek koruptif sedemikian itu tidak dapat digeneralisir. Tapi bagi kalangan advokat yang takut perkara kliennya nanti akan kalahkan, cenderung akan mencari jalan dan segala cara untuk dapat memenangkan perkaranya. Praktek tersebut juga terjadi di Pengadilan Negeri Mamuju antara lain biaya pendaftaran yang harus dibayar dengan harga yang tidak murah yang melebihi dari ketentuan telah ditetapkan, juga terjadi ketika pencari keadilan ingin mengambil salinan putusan yang semestinya menjadi haknya, namun akan di berikan jika pihak tersebut memberikan uang kepada oknum petugas pengadilan, karena tanpa uang maka akan sulit untuk mendapatkannya.

Indonesia telah memiliki lembaga pengawasan yang telah di berikan kewenangan oleh undang-undang untuk mengawasi semua lembaga yang seluruh atau sebagian anggarannya bersumber dari APBN dan/atau APBD, sehingga seharusnya lembaga pelayanan public melaksanakan pelayanannya dengan baik yang sesuai dengan tata kelola yang baik agar masyarakat merasakan pelayanan yang baik dan maladministrasi pun tidak seharusnya terjadi, namun pada kenyataannya dilapangan terjadi beberapa penyimpangan khususnya dalam pelaksanaan pelayanan peradilan di pengadilan negeri mamuju, kita tahu bahwa Ombudsman adalah lembaga yang berwenang mengawasi pelayanan public termasuk pelayanan pengadilan negeri mamuju.

Hal ini menindikasikan adanya pengelolaan administrasi dalam pelayanan publik di Pengadilan negeri mamuju yang tidak berjalan dengan baik. Berdasarkan UU Nomor 25 tahun 2009 tentang pelayanan publik, badan peradilan merupakan bagian dari salah satu penyedia layanan publik. Sehingga peradilan dituntut beroperasi berbasis pada pelayanan. Karena itu perbaikan pelayanan publik dengan menjalankan tata kelola administrasi yang baik harus menjadi perhatian khusus oleh Ombudsman Republik Indonesia Perwakilan Sulawesi Barat.

\section{METODE}

\subsection{Jenis Penelitian}

Jenis Penelitian yang digunakan adalah penelitian kualitatif yaitu adalah penelitian yang bertujuan menjelaskan fenomena dengan melalui pengumpulan data dengan pendekatan yuridis normatif dan yuridis empiris

\subsection{Lokasi Penelitian}

Penelitian ini dilakukan di Ombudsman Perwakilan Sulawesi Barat dan Pengadilan Negeri Mamuju

\subsection{Sumber Data}

Adapun Sumber data yang digunakan dalam penelitian ini adalah :

a) Data sekunder, yaitu data yang bersumber dari peraturan perundang-undangan yang korelasi dengan pokok-pokok permasalahan dalam penelitian ini serta buku-buku literature yang berkaitan dengan objek penelitian.

b) Data primer, yaitu data yang bersumber dari wawancara beberapa narasumber yang berhungungan dengan objek penelitian. 


\subsection{Narasumber}

Narasumber dalam penelitian berasal dari Pengadilan Negeri Mamuju, Perwakilan Ombudsman RI Sulawesi Barat, Peradi Cabang Sulawesi Barat, dan LBH Citra Justicia. Dalam Dalam pemilihan Narasumber dalam penelitian ini adalah narasumber yang terlibat langsung pada objek penelitian. Adapun daftar nama narasumber dapat di liat pada tabel berikut.

Tabel 1

Daftar Nama Narasumber Yang Diwawancara

\begin{tabular}{|c|c|c|c|}
\hline No & Nama & Pekerjaan/Jabatan & Domisili \\
\hline 1 & Harly Yunus & Panitera PN Mamuju & Mamuju \\
\hline 2 & $\begin{array}{l}\text { H Surahman } \\
\text { Hasan }\end{array}$ & Sekretaris PN Mamuju & Mamuju \\
\hline 3 & Lukman Umar & $\begin{array}{l}\text { Kepala Perwakilan Ombudsman } \\
\text { Sulawesi Barat }\end{array}$ & Mamuju \\
\hline 4 & $\begin{array}{l}\text { Muhammad } \\
\text { Sukriadi Azis }\end{array}$ & $\begin{array}{l}\text { Asisten Pemeriksaan Laporan } \\
\text { Ombudsman Perwakilan Sulawesi } \\
\text { Barat }\end{array}$ & Mamuju \\
\hline 5 & $\begin{array}{l}\text { Sekarwuning } \\
\text { Manfaati }\end{array}$ & $\begin{array}{l}\text { Asisten PVL Ombudsman } \\
\text { Perwakilan Sulawesi Barat }\end{array}$ & Mamuju \\
\hline 6 & Nasrum & Ketua Peradi Cab. Mamuju Raya & Mamuju \\
\hline 7 & $\begin{array}{l}\text { Ester Sambo } \\
\text { Pailin }\end{array}$ & Advokat LBH Citra Justicia & Mamuju \\
\hline
\end{tabular}

Sumber: Hasil identifikasi Narasumber Tahun 2019

\subsection{Analisis Data}

Data yang berhubungan dengan fungsi pengawasan Ombudsman terhadap pelaksanaan tata kelola administrasi pengadilan negeri mamuju dan analisa kualitatif dengan mengumpulkan Data-data primer dan sekunder kemudian akan di kaji dan disimpulkan.

\section{HASIL DAN PEMBAHASAN}

\subsection{Ombudsman}

\section{a. Histori Ombudsman Republik Indonesia Perwakilan} Sulawesi Barat

Ombudsman Perwakilan Sulawesi Barat adalah ombudsman perwakilan yang ke 28 terbentuk pada 20 Oktober 2013 dengan pengurus pertama kali di pilih Lukman Umar, S.Pd., M.Si sebagai kepala perwakilan pertama di Sulawesi barat. Saat ini jumlah personil di Ombudsman Republik Indonesia Perwakilan Sulawesi Barat berjumlah 17 Orang dengan uraian sebagai berikut: Kepala Perwakilan Ombudsman Republik Indonesia Perwakilan Sulawesi Barat 1 Orang, Asisten berjumlah 10 orang, PNS 2 Orang, Satpam 2 Orang, Pramu bakti 2 Orang.

Pada pasal 9 ayat (2) huruf b Peraturan Pemerintah Republik Indonesia No. 21 Tahun 2011 Tentang Pembentukan, Susunan, dan Tata Kerja Perwakilan Ombudsman Repubik Indonesia di daerah disebutkan bahwa Paling banyak 5 orang asisten pada perwakilan Ombudsman di daerah, namun Lukman Umar Kepala Perwakilan Ombudsman mengatakan jumlah asisten pada Ombudsman Sulawesi Barat adalah 10 orang, jadi 5 orang adalah asisten dari Ombudsman Perwakilan Sulawesi Barat sendiri dan 5 orang lagi adalah asisten titipan dari Ombudsman RI, lebih lanjut Lukman Umar mengatakan bahwa hal tersebut dilakukan karena jika hanya 5 orang asisten ombudsman maka sangat kekurangan personil sehingga optimalisasi tugas tidak dapat berjalan maksimal.
Adapun Tingkat Pendidikan Personil Ombudman Perwakilan Republik Indonesia Perwakilan Sulawesi Barat sesuai pada Tabel 2.

Tabel 2

Pendidikan personil Ombudsman Republik Indonesia Perwakilan Sulawesi Barat.

\begin{tabular}{lccc}
\hline No. & Pendidikan & Jumlah personil & Persentase $\%$ \\
\hline 1. & S2 & 2 Orang & 11,8 \\
2. & S1 & 12 Orang & 70,6 \\
3. & SMA & 3 Orang & 17,6 \\
\hline & Jumlah & 17 Orang & 100 \\
\hline
\end{tabular}

Sumber: Data Ombudsman RI Perwakilan Sulawesi Barat

Berdasarkan tabel diatas maka dapat dijelaskan bahwa tingkat pendidikan personil Ombudsman RI Perwakilan Sulawesi Barat bahwa Tingkat Pendidikan S2 sebanyak 2 orang atau 11,8\% dari total personil, Tingkat Pendidikan S1 sebanyak 12 Orang atau 70,6\% dari total personil dan Tingkat Pendidikan SMA 3 Orang atau 17,6 \%, jika di tinjau dari Sumber daya Manusia dari tingkat pendidikan cukup memadai.

b. Tugas pokok dan fungsi personil Ombudsman Perwakilan Sulawesi Barat

1) Kepala Perwakilan Ombudsman

Kepala Perwakila Ombudsman Betanggungjawab atas dimulainya pemeriksaan dan penutupan laoran kecuali adanya Pelaksanan Harian (PLH) yang ditunjuk atas kondisi tertentu misalnya Kepala Perwakilan dalam kondisi sakit, keluar kota atau karena kondisi yang mengharuskan dimana kondisi tersebut dibenarkan oleh peraturan perundang-undangan.

2) Keasistenan Pencegahan

Keasistenan Pencegahan bertugas pokok melakukan pencegahan tindakan maladministrasi lembaga pelayanan publik, koordinasi dengan pengawas internal penyelenggara layanan dalam rangka melakukan pencegahan tindakan maladministrasi, membangun keja sama, melakukan sosialisasi, investigasi sitemik, menyampaikan saran untuk perbaikan terhadap kebijakan untuk penyempurnaan institusi pelayanan publik, dan melakukan tugas lain yang diberikan oleh Ombudsman dan/atau Kepala perwakilan.

3) Keasistenan Penerimaan dan Verifikasi Laporan (PVL) Keasistenan Penerimaan dan Verifikasi Laporan berfungsi melaksanakan penerimaan laporan, pencatatan dan verifikasi laporan, fungsi ini yang mennetukan apakah laporan memenuhi syarat untuk di teruskan pada tahap selanjutnya atau tidak.

4) Keasistenan Pemeriksaan Laporan

Keasistenan Pemeriksaan Laporan berfungsi untuk melaksanakan penyelesaian laporan pada tahapan pemeriksaan setelah tahap PVL menyatakan layak untuk di periksa

\subsection{Tata Kelola Administrasi Pengadilan Negeri Mamuju} Setelah diterbitkannya Peraturan Mahkamah Agung Republik Indonesia Nomor 7 Tahun 2015 tentang Organisasi dan Tata kerja Kepaniteraan dan Kesekretariatan Peradilan, maka panitera dan sekretaris tidak satu orang lagi yang menjabat sehingga dalam pelaksanaan pelayanan administrasi di pengadilan di bagi 2 yaitu administrasi perkara dan administrasi umum dimana administrasi umum di bawahi langsung oleh sekretaris pengadilan negeri dan administrasi 
perkara di bawahi langsung oleh panitera. Sebagaimana di atur pada Perma No. 7 Tahun 2015 sebagai berikut:

Dalam pelaksanaan admistrasi, di pengadilan negeri dibagi dua administrasi yaitu administrasi perkara dan administras umun sehingga fungsi pelaksana teknis administrasi perkara dapat berjalan dengan baik, diantaranya adalah pengelolaan administrasi perkara Perdata, perkara Pidana, perkara Khusus serta bertanggungjawab atas penyajian data perkara dan transparansi perkara.

Panitera juga bertugas dalam pelaksansaan mediasi, pembinaan teknis kepaniteraan dan jurusita serta melaksanakan fungsi yang di berikan oleh Ketua Pengadilan Negeri. Sedangkan sekretaris bertugas dalam menjalankan administrasi umum dimana fungsinya adalah bartugas dalam penyiapan perencanaan program dan anggaran, urusan kepegawaian, urusan keuangan, penataan organisasi dan tata laksana, mengurus surat menyurat, arsip perlengkapan dan lain-lain yang tidak berhubungan dengan administrasi perkara. Dalam melaksanakan tugasnya maka harus mengedapankan asas Adil dan tidak diskriminatif, cermat, santun dan ramah, Profesional, tidak mempersulit serta tidak menyimpang dari procedural.

\subsection{Pengaduan atas Pelayanan Pengadilan}

Pelaksanaan pelayanan publik di pengadian negeri mamuju tentu harus ada akses pengaduan oleh masyarakat atau para pencari keadilan atas pelayanan yang menurut mereka tidak sesuai dengan tata kelola atau paling tidak mereka merasa tidak puas dengan pelayanan tersebut, sehingga pada Surat Keputusan Ketua Mahkamah Agung No. 026/KMA/SK/II/2012 memberikan akses pengaduan dengan menetapkan bahwa Masyarakat berhak mengadukan pelayanan publik pengadilan karena penyelenggara tidak menaksanakan kewajiban dan/atau melanggar larangan serta pelaksana tidak memberikan pelayanan sesuai dengan standar pelayanan yang telah ditetapkan.

Dalam hal terjadi pelanggaran atau pelayanan tidak sesuai dengan standar pelayanan maka masyarakat dapat mengadukan kepada pengawas internal dengan syarat bahwa kerjadian tersebut tidak lebih dari 30 hari setelah kejadian saat melakukan pengaduan secara tertulis dan akan diterima oleh pengadilan dengan memberikan bukti tertulis tanda terima aduan, dari aduan tersebut penyelenggara wajib memberikan tanggapan paling lama 14 hari sejak menerima aduan tersebut, jika materi aduan tidak lengkap maka pengadu akan di berikan kesempatan untuk memperbaiki selama 30 hari, jika tidak ada perbaikan maka pengadu di anggap mencabut pengaduannya.

\subsection{Penyelesaian Pengaduan oleh Penyelenggara Pelayanan Pengadilan}

Pengadilan wajib memeriksa jika ada pengaduan dari masyarakat mengenai pelayanan yang di selenggarakan Namun dalam memeriksa pengaduan, penyelenggara wajib independen, nondiskriminasi, tidak memihak, dan tidak memungut biaya. Pemeriksaan aduan harus di jaga kerahasiaannya. Aduan tersebut harus di putuskan hasilnya paling lambat 60 hari sejak berkas pengaduan dinyatakan lengkap dan Keputusannya wajib di sampaikan kepada pihak pengadu paling lambat 14 hari sejak diputuskan.
3.5. Efektifitas fungsi pengawasan Ombudsman Republik Indonesia Perwakilan Sulawesi Barat Terhadap Pelaksanaan Tata Kelola administrasi di Pengadilan Negeri Mamuju

Sebagaimana tertuang dalam PO No. 30 Tahun 2018 Tentang Susunan Organisasi dan Tata Kerja Asisten Ombudsman Republik Indonesia bahwa fungsi, tugas dan kewenangan Ombudsman yang dilaksanakan oleh keasistenan Ombudsman Perwakilan di bagi tiga fungsi yaitu : (i) Fungsi Pencegahan, (ii) Fungsi penerimaan dan verifikasi laporan, (iii) dan Fungsi Pemeriksaan Laporan.

\section{a. Fungsi Pencegahan}

Telah ditegaskan di Peraturan Ombudsman (PO) No. 30 Tahun 2018 bahwa fungsi Ombudsman dalam pencegahan maladministrasi pelayanan publik di laksanakan oleh Keasistenan Pencegahan, kemudian Keasistenan Pencegahan harus melakukan koordinasi dengan pengawas internal penyelenggara layanan dalam rangka pencegahan maladministrasi, melakukan sosialisasi, serta melakukan tugas lain yang diberikan Ombudsman dan/atau Kepala perwakilan.

Dalam melakukan pencegahan, Keasistenan pencegahan harusnya melakukan sosialisasi secara massif agar fungsi Pencegahan dapat tercapai secara maksimal, dan dilakukannya perbaikan kebijakan, penyempurnaan organisasi dan/atau prosedur pelayanan publik sehingga dapat meminimalisir terjadinya maladministrasi, namun pada kenyataannya yang terjadi dilapangan khususnya fungsi pengawasan Ombudsman terhadap pelaksanaan tata kelola administrasi di Pengadilan Negeri Mamuju di lihat dari fungsi pencegahan ternyata kurang efektif karena bahkan Ombudsman Perwakilan Sulawesi Barat tidak pernah sekalipun melakukan sosialisasi ke pengadilan negeri Mamuju hal ini dapat di buktikan dengan pernyataan beberapa Narasumber melalui wawancara langsung yang dilakukan.

Nasrum (Ketua Peradi Cabang Mamuju Raya: wawancara tanggal 20 Februari 2020)seorang pengacara mengatakan bahwa semua pengacara harusnya tahu sampai dimana batasan kewenangan Ombudsman dalam pengawasan di Pengadilan Negeri Mamuju sehingga pengacara atau pencari keadilan dapat mengambil langkah apabila memang diduga terjadi maladministrasi di lingkungan Pengadilan Negeri Mamuju, namun pada kenyataannya bulan Desember Tahun 2019 ada salah satu advokat yang melapor ke Ombudsman mengenai tidak diterimanya eksepsinya padahal substansi dari laporannya adalah mengenai gugatan sederhana, lanjut nasrum bahwa gugatan sederhana tidak ada upaya untuk eksepsi mungkin belum dipahami oleh Pelapor, dan proses persidangan merupakan bukan wilayah kewenangan Ombudsman.

Dari hasil wawancara tersebut di atas bahwa Ombudsman Republik Indonesia Perwakilan Sulwesi Barat kurang melakukan Sosialisasi di lingkungan peradilan Khususnya di Pengadilan Negeri Mamuju, karena dilihat dari komentar Nasrum di atas seharusnyaa setelah terjadinya pelaporan maka Ombudsman seharusnya melakukan sosialisasi secara massif di lingkungan Pengadilan Negeri khususnya Pengadilan Negeri Mamuju.

Demikian juga yang dikatakan oleh Ester Sambo Pailin (Advokat dari LBH Citra Justicia Sulbar Mamuju : wawancara tanggal 19 Februari 2020) seorang pengacara bahwa Ombudsman tidak pernah melakukan di Sosialisasi di lingkungan Pengadilan Negeri Mamuju sehingga kami sebagai pengacara yang lebih intens beracara di Pengadilan Negeri 
Mamuju tidak sampai mengetahui sampai dimana wewenang dan batasan-batasan wewenang Ombudsman dalam mengawasi tata kelola administrasi Pengadilan Negeri Mamuju, saya juga secara pribadi belum pernah mendampingi klien yang yang terkait dengan Ombudsman sehingga saya juga tidak mendalami mengenai fungsi dan wewenang Ombudsman. Namun secara umum saya paham bahwa Ombudsman mengawasi penyelenggara pemerintah dalam pelayanan publik.

Hal tersebut diatas dikuatkan lagi oleh pernyataan Yunus (Panitera Pengadilan Negeri Mamuju: wawancara tanggal 18 Februari 2020) bahwa Ombudsman tidak pernah datang ke Pengadilan dan melakukan sosialisasi atau pengawasan langsung ke kantor kami mengenai fungsinya, namun dalam hal pelaksanaan pelayanan, kami di sini sudah ada petunjuk teknis mengenai standar pelaksanaan pelayanan Pengadilan, sehingga menjadi pedoman bagi kami dalam melaksanakan pelayanan, adapun kalau ada aduan di pegawas internal atau keluhan oleh masyarakat kepada kami sampai saat belum ada hingga saat ini. Namun kami tidak tahu kalau ada keluahan keluar namun hal itu kami siap untuk klarifikasi jika memang ada, bisa jadi dugaan maladministrasi atau pelanggara itu dilakukan oleh oknum atau kesalah pahaman oleh pengguna layanan. Untuk mengetahui jumah laporan terhadap penyelenggara peradilan dari tahun 2013 sampai 2019 berdasarkan kabupaten sebagaimana pada Tabel 3:

Tabel 3

Jumlah Laporan terhadap Penyelenggara Peradilan dari Tahun 2013 sampai 2019

\begin{tabular}{lcccccccc}
\hline \multirow{2}{*}{ No Kabupaten } & \multicolumn{7}{c}{ Tahun } \\
\cline { 2 - 8 } & 2013 & 2014 & 2015 & 2016 & 2017 & 2018 & 2019 \\
\hline 1 Polewali Mandar & 0 & 1 & 0 & 2 & 1 & 2 & 1 \\
2 Mamuju & 0 & 1 & 0 & 2 & 1 & 0 & 0 \\
3 Majene & 0 & 1 & 0 & 0 & 0 & 0 & 0 \\
4 Mamasa & 0 & 0 & 1 & 0 & 0 & 0 & 0 \\
\hline \multicolumn{1}{c}{ Jumlah } & 0 & 3 & 1 & 4 & 2 & 2 & 1 \\
\hline
\end{tabular}

Sumber: Asisten PVL Ombudsman Perwakilan Sulawesi Barat

Tabel 3 di atas maka dapat di jelaskan bahwa dari tahun 2013 sampai 2019 laporan terhadap penyelenggara peradilan kepada Ombudsan Perwakilan Sulawesi Barat adalah sejumlah 13 laporan dengan uraian sebagai berikut, pada tahun 2013 tidak ada satupun laporan, tahun 2014 Polewali Mandar, mamuju, dan majene masing-masing 1 laporan sedangkan mamasa tidak ada laporan, tahun 2015 Polewali Mandar, mamuju, dan majene tidak ada satupun laporan sedangkan mamasa 1 laporan, tahun 2016 Polewali mandar dan mamuju masing-masing 2 laporan sedangkan Majene dan Mamasa tidak ada laporan, tahun 2017 Polewali Mandar dan Mamuju masing-masing 1 laporan sedangkan Majene dan Mamasa tidak ada laporan, tahun 2018 Polewali Mandar 1 laporan sedangkan Mamuju, Majene dan Mamasa tidak ada laporan, tahun 2019 Polewali Mandar 1 laporan sedangkan Mamuju, Majene dan Mamasa tidak ada laporan.

Untuk lebih lebih fokus kepada Pengadilan Negeri Mamuju dapat di jelaskan bahwa Ombudsman Perwakilan Sulawesi Barat mendapatkan Laporan mengenai Pelayanan Pengadilan Negeri Mamuju sejak tahun 2013 sampai 2019 dapat di jelaskan sebagai berikut:

1) Tanggal 22 Desember 2014 laporan mengenai Dugaan penundaan berlarut oleh pengadilan negeri Mamuju. Hasil akhirnya adalah laporan ditutup karena bukan merupakan maladsministrasi karena merupakan proses peradilan yang sesuai hukum acara.

2) Tanggal 13 Maret 2017 Dugaan permintaan uang oleh petugas pengadilan Negeri mamuju terhadap pengurus surat keterangan tidak pernah dijatuhi hukuman pidanan, hasil akhirnya adalah laporan di tutup karena pembayaran yang dimaksud adalah memang adanya pembayaran yang harus pungut yaitu PNBP Penerimaan Negara bukan Pajak yang merupakan sah menurut hukum dan bukan merupakan maladministrasi.

Sehingga dari 2 laporan tersebut diatas bahwa semua laporan tersebut bukan merupakan maladministrasi dan fenomena ini merupakan akibat kurangnya pengetahuan dari masyarakat mengenai wewenang ombudsman, selain itu ada juga pengaduan yang di lakukan oleh salah satu pengacara yang tidak dimasukan dalam register pendaftaran pengaduan Ombudsman, karena hal itu bukan merupakan wewenang ombudsman, yaitu mengenai tidak di terimanya eksepsi dalam gugatan sederhana, padahal dalam hukum acara gugatan sederhana tidak ada upaya eksepsi.

Dari hal tersebut di atas semestinya menjadi perhatian Ombudsman Perwakilan Sulawesi Barat untuk melakukan sosialisasi secara massif agar pemahaman masyarakat terhadap fungsi Ombudsman khususnya dalam pengawasan pelaksanaan tata kelola administrasi Pengadilan Negeri Mamuju terutama pada fungsi Pencegahan, fungsi pencegahan Ombudsman harusnya tidak hanya berhasil melakukan pencegahan maladministrasi saja namun bagaimana agar masyarakat memahami betul fungsi pengawasan Ombudsman khususnya terhadap pelaksanaan tata kelola administrasi pengadilan negeri mamuju, sehingga benar-benar terjadi pelayanan publik yang lebih baik serta masyarakat pun tahu bahwa hal-hal mana saja yang dapat di laporkan atau yang dapat diduga sebagai maladministrasi.

Selain penelitian melalui wawancara peneliti juga membuat kuesioner untuk membuat penilaian tingkat efektifitasnya Fungsi Ombudsman terhadap pelaksanaan tata kelola administrasi pengadilan negeri mamuju menurut Fungsi Pencegahan, pada kuesioner mengajukan 4 pilihan jawaban yang di sediakan dalam pertanyaan mengenai hal tersebut, lebih banyak yang menjawab kurang efektif sebagaimana pada Tabel 4 dibawah ini;

Tabel 4

Jawaban Informan tentang efektifitas fungsi Ombudsman terhadap pelaksanaan tata kelola administrasi pengadilan Negeri mamuju Menurut Fungsi Pencegahan.

\begin{tabular}{cccc}
\hline No & Pilihan Jawaban & $\begin{array}{c}\text { Frekuensi Informan } \\
\text { Jumlah Orang }\end{array}$ & $\begin{array}{c}\text { Persentase } \\
\%\end{array}$ \\
\hline 1 & Sangat Efektif & 6 & 3 \\
2 & Cukup Efektif & 20 & 10 \\
3 & Kurang Efektif & 22 & 11 \\
4 & Tidak Efektif & 2 & 1 \\
\hline & Total & 50 & 100 \\
\hline
\end{tabular}

Sumber: Data sekunder diolah Februari 2020

Berdasarkan uraian diatas maka dapat disimpulan bahwa efektifitas fungsi pengawasan Ombudsman RI perwakilan Sulawesi Barat tehadap pelaksanaan tata kelola administrasi di Pengadilan Negeri Mamuju Kurang Efektif

\section{b. Fungsi Penerimaan dan Verifikasi Laporan}

Setiap masyarakat berhak untuk menyampaikan pengaduan atas pelayanan publik yang dirasakan merugikan. Pengaduan dapat disampaikan secara langsung kepada 
pengawas internal instansi penyelenggara pelayanan atau dapat juga menyampaikan kepada Ombudsman Republik Indonesia Pasal 1 angka 5 Undang-Undang Nomor 37 tahun 2008 menyebutkan bahwa Pelapor merupakan warga negara Indonesia atau penduduk yang menyampaikan laporan kepada Ombudsman Republik Indonesia. Sementara, pihak yang dapat dilaporkan atau yang berposisi sebagai terlapor adalah penyelenggara negara dan pemerintahan yang diduga melakukan mal administrasi sesuai Pasal 1 angka 6 UndangUndang Nomor 37 Tahun 2008 tentang Ombudsman Republik Indonesia. Maladministrasi dapat terjadi semua lingkup pelayanan publik yaitu dalam lingkup pelayanan administrasi publik, pelayanan barang publik dan pelayanan jasa publik. Ketiga ruang lingkup tersebut mencakup berbagai sector pelayanan seperti pelayanan kesehatan, jaminan social, energy, perbankan, pendidikan, usaha, dan berbagai sector strategis lainnya.

Ketiga lingkup pelayanan public tersebut menunjukkan penyelenggaraan public oleh Negara kepada masyarakat menyebabkan luasnya objek pengawasan Ombudsman Republik Indonesia, salah satu yang menjadi objek pengawasan Ombudsman Republik Indonesia adalah pelayanan peradilan. Dalam melaksanakan fungsi ombudsman tentu harus teliti dalam menindaklanjuti laporan dengan sehingga dalam pelaksanaan fungsi Penerimaan dan Verifikasi Laporan masyarakat harus dilaksanakan dengan teliti. Penanganan laporan oleh Ombudsman Republik Indonesia senantiasa harus berpedoman pada asas tersebut adalah prinsip independensi, non diskriminasi, tidak memihak dan tidak memungut biaya sesuai Pasal 29 Undang-Undang Nomor 37 Tahun 2008 tentang Ombudsman Republik Indonesia.

Ombudsman Republik Indonesia juga perlu mengedepankan prinsip kehati-hatian agar tidak melampaui kewenangan. Konsistensi pada asas atau prinsip tersebut sejalan dengan filosofi keberadaan Ombudman sebagai pihak tempat masyarakat menyampaikan keluhan sehingga menjadi lembaga yang dipercaya oleh masyarakat dan aparatur Negara lainnya. Keberadaannya ini merupakan tantangan bagi Ombudsman Republik Indonesia dalam pelaksanaan tugas dan tanggung jawabnya.

Lukman Umar (Kepala Ombudsman Republik Indonesia Perwakilan Sulawesi Barat: wawancara tanggal 18 Februari 2020) penerimaan laporan tidak harus formal kadang hanya cerita santai, lewat whatsapp karena dalam penerimaan laporan jika dilakukan laporan secara lisan maka dibuatkan pernyataan bahwa yang dia laporkan adalah benar, namun setiap laporan terlebih dahulu akan di tanyakan apakah sudah melakukan aduan di pengawas internal terlapor atau belum, jika belum maka akan di arahkan untuk melakukan pengaduan secara internal dahulu kecuali jika keselamatannya terancam, pangkat dan jabatannya dengan di buatkan surat pernyataan bahwa keterangannya benar Lanjut Lukman Umar mengatakan bahwa dalam menerima laporan maka akan di lakukan verifikasi untuk memeriksa persyaratan laporan apakah sudah terpenuhi atau tidak, verifikasi tersebut adalah : Verifikasi Formal yaitu identitas pelapor, legal standing dan Verifikasi Materil yaitu apakah masuk kewenangan Ombudsman, apakah tidak sementara berproses di pengawas internal terlapor atau pengadilan, apakah pelapor tidak pernah mencabut laporan dan melapor kembali dengan laporan yang sama, dan benar bahwa ada masalah pada instansi yang dilaporkan jika dinilai tidak ada masalah maka laporan tidak di lanjutkan.
Pada proses ini fungsi penerimaan dan verifikasi laporan sangat berperan dalam penyaringan laporan yang masuk untuk mencegah ombudsman melampaui kewenangan dalam pengawasan sesuai dengan Undang-undang No 37 Tahun 2008 tentang Ombudsman. Untuk mengetahui bagaimana fungsi Penerimaan dan Verifikasi Laporan dapat di lihat pada Tabel 5 berikut:

Tabel 5

Jenis Akses Masyarakat atau Pelapor dan Jumlah yang Teregistrasi SIMPEL Bidang PVL Ombudsman RI Perwakilan Sulawesi Barat

\begin{tabular}{llcc}
\hline & \multicolumn{1}{c}{ Jenis Akses } & \multicolumn{2}{c}{ Jumlah akses } \\
\cline { 3 - 4 } & & Laporan & $\begin{array}{c}\text { Konsultasi } \\
\text { Non Laporan }\end{array}$ \\
\hline 1 & Datang langsung & 63 & 35 \\
2 & Telepon & 20 & 2 \\
3 & Email & 2 & 0 \\
4 & Surat & 10 & 0 \\
5 & Media Sosial (FB atau IG) & 4 & 0 \\
6 & Whatsapp & 30 & 1 \\
\hline & & 129 & 39 \\
\hline
\end{tabular}

Sumber: SIMPEL Ombudsman RI Perwakilan Sulawesi Barat Tahun 2019

Data diatas menjelaskan bahwa dalam melayani pelapor maladministrasi Ombudsman membuka ruang akses pelaporan untuk selanjutnya di lakukan verifikasi apakah laporan tersebut merupakan wewenang ombudsman atau bukan, seperti penjelasan Lukman Umar bahwa data tersebut diatas merupakan data keseluruhan yang melapor perode tahun 2019 namun ada juga beberapa yang hanya sampai pada konsultasi saja tanpa lanjut ke laporan karena berbagai macam alasan yang kami temukan selama ini yaitu antara lain: ada yang takut karena yang terlapor merupakan atasannya atau orang yang berpengaruh sehingga mereka tidak melanjutkan ke tahap laporan resmi, padahal dengan regulasi yang ada, kita dapat merahasiakan identitas pelapor, selain itu ada juga yang hanya konsultasi dan tidak sampai pada pelaporan karena di identifikasi bahwa bukan merupakan wewenang Ombudsman sehingga tidak dapat di lanjutkan sehingga tahap verifikasi atas laporan tersebut di hentikan sampai pada konsultasi saja tidak sampai pada proses registrasi laporan resmi (Kepala Ombdudsman RI Perwakilan Sulawesi Barat: wawancara 18 Februari 2020).

Selain penelitian melalui wawancara peneliti juga membuat kuesioner untuk mendapat penilaian tingkat efektifitasnya Fungsi Ombudsman terhadap pelaksanaan tata kelola administrasi pengadilan negeri mamuju menurut Fungsi Verifikasi dan Penerimaan Laporan, berdasarkan pada kuesioner diajukan 4 pilihan jawaban yang di sediakan dalam pertanyaan mengenai hal tersebut, lebih banyak yang menjawab Cukup Efektif sebagaimana pada tabel 6 dibawah ini;

Tabel 6

Jawaban Informan tentang Efektifitas Fungsi Ombudsman Terhadap Pelaksanaan Tata Kelola Administrasi Pengadilan Negeri Mamuju Menurut Fungsi Verifikasi dan Penerimaan Laporan.

\begin{tabular}{|c|c|c|c|}
\hline No & Pilihan Jawaban & Informan Jumlah Orang & Persen $(\%)$ \\
\hline 1 & Sangat Efektif & 9 & 4,5 \\
\hline 2 & Cukup Efektif & 28 & 14 \\
\hline 3 & Kurang Efektif & 12 & 6 \\
\hline 4 & Tidak Efektif & 1 & 0,5 \\
\hline & Total & 50 & 100 \\
\hline
\end{tabular}

Sumber Data : secunder diolah Februari Tahun 2020 
Dari data dan keterangan diatas serta menurut Tabel 8, menunjukkan bahwa dalam pelaksanaan fungsi pengawasan Ombudsman Republik Indonesia Perwakilan Sulwesi Barat menurut Fungsi Verifikasi dan Pemeriksaan Laporan dapat di kategorikan Cukup Efektif.

\section{c. Fungsi Pemeriksaan Laporan}

Keasistenan Pemeriksaan Laporan Menjalankan Fungsi Penerimaan Laporan Ombudsman yaitu Melakukan Pemeriksaan substansi laporan yang tercakup dalam ruang lingkup kewenangan Ombudsman, Melakukan invetigasi atas prakarsa sendiri terhadap dugaan maladministrasi dalam penyelenggaraan pelayanan public, Melakukan koordinasi dengan pengawas internal instansi penyelenggara layanan untuk pemeriksaan laporan, Melakukan evaluasi, dan pelaporan kegiatan dan Melakukan tugas lain yang diberikan oleh Ombudsman dan/atau Kepala perwakilan.

Dalam melaksanakan fungsi penerimaan laporan, Ombudsman harus benar-benar melaksanakan tugas sebagaimana diatur dalam PO No. 30 tahun 2018 dan harusnya fungsi ini lah yang menjadi kunci keberhasilan Ombudsman dalam menjalankan tugasnya dalam memberikan keadilan terhadap pelapor demi tercapainya pelayanan publik serta tata kelola pemerintahan yang baik. Setelah Asisten Verifikasi dan Penerimaan Laporan dan menyatakan bahwa laporan tersebut adalah merupakan kewenangan Ombudsman Perwakilan Sulawesi Barat maka selanjutnya akan diserahkan kepada asisten yang menjalankan fungsi Pemeriksaan Laporan untuk di lakukan pemeriksaan substansi atas laporanya, maka menurut Pasal 26 Peraturan Ombudsman (PO) No. 30 Tahun 2018 maka asisten Pemeriksaan Laporan berwenang melakukan Ajudikasi. Namun sampai saat ini petunjuk teknis pelaksanaan Ajudikasi di wilayah perwakilan belum ada, itulah yang menjadi hambatan terhadap pelaksanaan pemeriksaan laporan secara maksimal, menurut Lukman Umar sudah ada beberapa pelapor yang mengajukan ajudikasi namun kami tidak bisa melakukannya karena kita tidak punya aturan teknis atau PO (Peraturan Ombudsman) mengenai ajudikasi, kemudian kami juga seharusnya sudah beberapa kali melakukan penggil paksa karena kami di dukung oleh undang-undang bahkan sudah ada MoU dengan kepolisian tapi anggarannya dari mana, polisi mau di pakai, asisten Ombudsman juga harus terlibat. Jika hal tersebut sudah dilakukan maka akan ada efek jera terhadap Institusi penyelenggara pelayanan publik yang lain (Kepala Perwakilan Ombudsman RI Perwakilan Sulawesi Barat: wawancara 18 Februari 2020)

Selain uraian diatas juga sampaikan oleh lukman umar bahwa dalam pemeriksaan laporan dahulu dilakukan perindividu namun sekarang dengan inovasi para asisten maka pemeriksaan laporan dilakukan dengan cara bekerja sama walaupun secara formal ada 1 orang yang bertanggungjawab, kami di tuntut menyelesaikan laporan $90 \%$ dari total laporan setiap tahun sementara anggaran tidak menutupi, jadi harus pandai-pandai mencari metode penyelesaian yang murah meriah dan bisa kena sasaran dan selesai tapi kalau kita bicara kualitas memang tidak bisa berkualitas, ya kalau ada 1 atau 2 aduan yang di apresiasi masyarakat, itu pandai-pandainya saja Humas saya menggoreng keluar, kalau tidak begitu maka ombudsman tidak akan dipandang (Kepala perwakilan Ombudsman Perwakilan Sulawesi Barat: wawancara tanggal 18 Februari 2020).
Selain penelitian melalui wawancara peneliti juga membuat kuesioner untuk mendapat penilaian tingkat efektifitasnya Fungsi Ombudsman terhadap pelaksanaan tata kelola administrasi pengadilan negeri mamuju menurut Fungsi Pemeriksaan Laporan, pada kuesioner tersebut diajukan 4 pilihan jawaban yang di sediakan dalam pertanyaan mengenai hal tersebut, lebih banyak yang menjawab Kurang Efektif sebagaimana pada tabel 7 dibawah ini;

\section{Tabel 7}

Jawaban Informan tentang Efektifitas Fungsi Ombudsman Terhadap Pelaksanaan Tata Kelola Administrasi Pengadilan Negeri Mamuju Menurut Fungsi Pemeriksaan Laporan.

\begin{tabular}{llcc}
\hline No & Pilihan Jawaban & $\begin{array}{c}\text { Frekuensi } \\
\text { Informan Jumlah } \\
\text { Orang }\end{array}$ & $\begin{array}{c}\text { Persentase } \\
\%\end{array}$ \\
\hline 1 & Sangat Efektif & 3 & 1,5 \\
2 & Cukup Efektif & 21 & 10,5 \\
3 & Kurang Efektif & 24 & 12 \\
4 & Tidak Efektif & 2 & 1 \\
\hline & & 50 & 100 \\
\hline
\end{tabular}

Sumber Data : data sekunder diolah Februari 2020

Dengan memperhatikan hal diatas menunjukkan bahwa fungsi pengawasan Ombudsman Republik Indonesia Perwakilan Sulawesi Barat jika dilihat dari fungsi pemeriksaan laporan Kurang Efektif.

\subsection{Faktor yang menjadi hambatan Ombudsman Republik Indonesia Perwakilan Sulawesi Barat dalam menjalankan perannya sebagai lembaga pengawasan dalam Pelaksanaan Tata Kelola Administrasi pada Pengadilan Negeri Mamuju}

a. Regulasi

Jika dilihat dari Fungsi yang tertuang dalam regulasi maka bisa menjadi implementasi kekuatan Ombudsman berdasarkan wewenangnya sesuai dengan UU No. 37 Tahun 2008 karena Ombudsman adalah Raksasa Lembaga Negara yang sedang tidur, jika menggunakan kewenangannya secara maksimal maka akan menjadi pengawas eksternal yang mampu mengontrol semua institusi penyelenggara pelayanan publik, hal tersebut beralasan dimana jika dilihat dari kewenangannya di dalam Undang-undang no. 37 Tahun 2008 maka dapat di lihat hal-hal yang bisa menjadi efek jera dan dapat lebih meminimalisir lagi kemungkinan maladministrasi terjadi, yaitu:

1) Ombudsman berwenang mengawasi semua Institusi atau lembaga yang sumber dananya merupakan sebagian atau seluruhnya menggunakan APBN dan/atau APBD Pasal 1 Undang-undang No. 37 Tahun 2008 tentang Ombudsman.

2) Menerbitkan rekomendasi mengenai penyelesaian Laporan, termasuk ganti rugi dan/atau rehabilitasi kepada pihak yang dirugikan Pasal 8 Huruf f Undangundang No. 37 Tahun 2008 tentang Ombudsman

3) Apabila terlapor tidak melaksanakan rekomendasi atau hanya sebagian rekomendasi dengan alasan yang tidak dapat diterima oleh ombudsman, maka Ombudsman dapat mempublikasikan Terlapor dan menyampaikan laporan kepada Dewan Perwakilan Rakyat dan Presiden. Pasal 38 ayat (4) Undang-undang No. 37 Tahun 2008 tentang Ombudsman

4) Terlapor dan atasan terlapor yang melanggar ketentuan sebagaimana dimaksud dalam point 1 dan 2 diatas maka 
yang bersangkutan dikenakan sanksi administrasi sesuai dengan ketentuan peraturan perundang-undangan Pasal 39 Undang-undang No. 37 Tahun 2008 tentang Ombudsman

5) Dalam hal terlapor dan saksi sebagaimana dmaksud dalam pasal 28 ayat (1) huruf a telah dipanggil 3 (tiga) kali berturut-turut tidak memenuhi panggilan dengan alasan yang sah, Ombudsman dapat meminta bantuan Kepolisian Negara Republik Indonesia untuk menghadirkan yang bersangkutan secara paksa Pasal 31 Undang-undang No. 37 Tahun 2008 tentang Ombudsman

6) Ombudsman dapat melakukan pemeriksaan ke Objek pelayanan publik tanpa pemberitahuan terlebih dahulu instansi yang dilaporkan dengan tetap memperhatikan ketentuan peraturan peraturan perundang-undangan, ketertiban dan kesusialaan. Pasal 34 Undang-undang No. 37 Tahun 2008 tentang Ombudsman

7) Jika ada yang menghalangi Ombudsman dalam melakukan pemeriksaan maka dipidana dengan pidana penjara paling lama 2 (dua) tahun atau denda paling banyak Rp. 1.000.000.000,00 (satu miliar rupiah). Pasal 44 Undang-undang No. 37 Tahun 2008 tentang Ombudsman

8) Selain itu Ombudsman juga memiliki hak imunitas dimana disebutkan bahwa dalam rangka melaksanakan tugas dan wewenangnya, Ombudsman tidak dapat ditangkap, ditahan, diinterogasi, dituntut, atau digugat dimuka pengadilan.

9) Ombudsman juga dapat melaksanakan ajudikasi berdasarkan peraturan perundang-undangan

Dari point diatas menunjukan betapa luas dan besarnya kewenangan ombudsman namun pada kenyataannya Ombudsman RI perwakilan Sulawesi Barat sampai saat ini tidak pernah melakukan ajudikasi dalam melaksanakan penyelesaian laporan, bukan karena tidak ada laporan tapi justru karena tidak adanya aturan teknis atau PO (peraturan Ombudsman) yang mengatur mengenai ajudikasi, sebagaimana Lukman Umar mengatakan bahwa sudah ada beberapa pelapor yang mengajukan ajudikasi namum kami tidak bisa melakukan karena belum adanya aturan teknis atau PO tentang ajudikasi. Berdasarkan hasil penelitian menunjukkan bahwa ombudsman perwakilan Sulawesi barat terhambat regulasi dalam melaksanakan fungsinya sebagai lembaga pengawasan yang mempunya wewenang melaksanakan ajudikasi.

\section{b. Sumber Daya Manusia}

Sumber Daya Manusia adalah sangat penting perannya dalam suatu insitusi bahkan sumberdaya manusia merupakan factor penentu kesuksesan suatu institusi, sehingga dapay dinyatakan bahwa sumber daya manusia merupakan motor penggerak pada institusi yang diperhitungkan dan harus dikembangkan kualitas dan/atau kuantitasnya untuk mencapai performa kerja yang maksimal.

Faktor penting untuk implementasi kebijakan agar efektif adalah Sumber Daya Manusia, Sumber Daya Manusia dapat di bagi 2 yaitu segi kuantitas dan segi kualitas, dari segi kuantitas berkaitan dengan jumlah Sumber Daya Manusia yang tersedia untuk berkontribusi secara fikiran dan secara fisik untuk institusinya. Sedangkan dari segi kualitas adalah berkaitan dengan mutu dan daya saing dalam suatu institusi.

Dalam pelaksanaan pengawasan Ombudsman perwakilan Sulawesi Barat terhadap pelaksanaan Tata Kelola
Administrasi pada pengadilan Negeri Mamuju berdasarkan Hasil penelitian bahwa secara kualitas Sumber Daya Manusia Ombudsman Perwakilan Sulawesi Barat sudah cukup Memadai hanya saja jika di tinjau dari luas wilayah Sulawesi Barat dan jangkauan kewenangan Ombudsman maka secara kuantitas Sumber Daya Manusia Ombudsman Perwakilan Sulawesi Barat belum memadai.

Berdasarkan hasil penelitian menunjukkan bahwa Sumber Daya Manusia merupakan salah satu factor yang menghambat pelaksanaan fungsi pengawasan ombudsman terhadap pelaksanaan Tata Kelola Administrasi di pengadilan Negeri Mamuju. Hal ini di buktikan dari hasil wawancara langsung dengan Lukman Umar bahwa dalam pelaksanaan tugas ombudsman secara teknis dilakukan oleh Asisten dan jumlah asisten saat ini ada 10 orang dan harus melaksanakan pemeriksaan laporan dan wewenang pengawasan yang sangat luas sehingga kadang semuanya tidak terjangkau oleh jumlah personil kami yang terbatas, seandainya sudah di buka Ombudsman Kabupaten maka pengawasan Ombudsman mungkin bisa lebih maksimal. Kepala Perwakilan Ombudsman Perwakilan Sulawesi Barat (wawancara tanggal 17 Februari 2020)

\section{c. Anggaran}

Pelaksanaan fungsi suatu institusi tentu harus di dukung oleh anggaran agar roda organisasi yang membutuhkan biaya operational dapat berjalan dengan baik sehingga anggaran merupakan factor yang sangat menunjang efektifnya perjalanan organisasi atau institusi. Sumber Daya Manusia yang memadai namun anggaran tidak mendukung maka isntitusi juga tidak dapat berjalan secara efektif.

Ombudsman bertugas mengawasi seluruh institusi yang sebagaian atau seluruh anggaran bersumber dari APBD dan/atau APBN sehingga bisa di katakana bahwa wilayah kerja Ombudsman sangatlah luas dengan kondisi anggaran yang serba terbatas, menurut Lukman Umar bahwa kita bisa melakukan panggil paksa jika sudah dilakukan panggilan ke tiga namun tidak di penuhi, dalam hal penggil paksa tersebut dapat diminta kepada kepolisian karena saat ini kita sudah ada MOU dengan Kepolisian mengenai hal tersebut namun untuk melaksanakan itu kita terbatas pada anggaran karena angaran kami sangat terbatas. Begitu pun dengan tugas para asisten yang semua asisten harus tahu semua permasalahan maladminstrasi dari seluruh institusi yang berada dibawah pengawasan kami. Jadi dalam hal pelaksanaan laporan Ombudsman diwajibkan menyelesaikan $90 \%$ dari total laporan pertahun sehingga menjadi kendala ketika anggaran tidak cukup lagi untuk menangani laporan tersebut, lanjut Lukman Umar mengatakan bahwa untuk mensiasati hal tersebut adalah dengan mengatur pembagian tugas para asisten dan tidak hanya menghadapi laporan yang menjadi tanggungjawabnya saja namun tetap bersama-sama asisten lain untuk membantu bilamana diperlukan walaupun sebenarnya bukan merupakan tanggungjawabnya. Sehingga bisa menefisienkan waktu dan anggaran agar bisa digunakan seminimal mungkin, dan saat rapat kerja terakhir saya menyampaikan bahwa Kerja di Ombudsman adalah 3/4 keikhlasan, karena jika berfikir mengenai anggaran maka keikhlasan dalam melaksanakan tugas akan rusak. Kepala Perwakilan Ombudsman Perwakilan Sulawesi Barat (wawancara tanggal 17 Februari 2020)

Berdasarkan pernyataan diatas menujukkan bahwa ombudsman terbatas dengan anggaran yang ada namun personilnya tetap berinisiatif dalam membuat langkah taktis 
dalam menjalankan tugasnya untuk tetap dapat berjalan semaksimal mungkin. Hal ini merupakan menjadi factor penghambat berjalananya fungsi pengawasan ombudsman terhadap pelaksanaan tata kelola administrasi di pengadilan negeri mamuju.

\section{d. Sosialisasi terhadap masyarakat}

Eksisnya suatu institusi merupakan hal yang menjadi pendukung berjalannya fungsi, sehingga untuk mencapai hal tersebut maka perlu bagi masyarakat untuk mengenal dan mengetahui fungsinya sehingga intitusinya bisa berjalan sebagaimana mestinya.

Dalam pelaksanaan fungsi pengawasan Ombudsman perwakilan Sulawesi Barat terhadap pelaksanaan tata kelola administrasi di pengadilan negeri mamuju belum tersosialiasasi dengan baik sehingga kebanyakan masyarakat belum tahu bahwa Ombudsman memiliki kewenangan dalam pengawasan terhadap pelaksanaan tata kelola administrasi pengadilan negeri mamuju sebagaimana dikatakan oleh Sekarwuni Manfaati bahwa pengetahuan masyarakat mengenai layanan public masih minim berdasarkan hasil dari beberapa kali sosialisasi Ombusdsman di lapangan dan kenyataannya masyarakat hanya mengetahui pelayanan public hanya, rumah sakit, kantor pemerintah daerah dan pelayanan public di PDAM sedangkan pengetahuan masyarakat mengenai pengadilan negeri juga merupakan bagian dari pelayanan public dan berada dibawah pengawasan Ombudsman sangat kurang. Asisten Ombudsman Perwakilan Sulawesi Barat (wawancara tanggal 20 Februari 2020)

Berdasarkan hal tersebut diatas menunjukkan bahwa dalam pelaksanaan fungsi pengawasan Ombudsman Perwakilan Sulawesi Barat pada pelaksanaan tata kelola administrasi pengadilan negeri mamuju sangat minim karena sosialisasi khusus mengenai hal ini sangat kurang sosialisasi bahkan bisa dikatakan tidak pernah dilakukan sosialisasi khusus mengenai pengadilan negeri merupakan berada dibawah pengawasan Ombudsman dan apa saja yang menjadi kewenangan dan batasan kewenangan Ombudsman terhadap pengawasan pelaksanaan tata kelola administrasi pengadilan negeri Mamuju.

\section{KESIMPULAN}

Kesimpulan penelitian ini bahwa efektifitas fungsi pengawasan Ombudsman Republik Indonesia Perwakilan Provinsi Sulawesi Barat terhadap Pelaksanaan Tata Kelola Administrasi di Pengadilan Negeri Mamuju secara umum dapat dikatakan cukup efektif karena justru memberikan rasa percaya diri kepada pelaksana pelayanan publik di Pengadilan Negeri Mamuju untuk menghindari stigma negatif dari masyarakat terhadap pelayaanan administrasi peradilan dan dengan menerapkan tata kelola administrasi yang telah di atur sehingga dapat mengurangi penyimpangan dalam pelaksanaan pelayanan pada lingkungan pengadilan negeri mamuju sehingga serta dapat meningkatkan kepercayaan publik. Namun jika memperhatikan efektifitas fungsi Ombudsman RI Perwakilan Sulawesi Barat di lihat dari fungsi Pencegahan, Penerimaan dan Verifikasi Laporan, dan Pemeriksaan Laporan maka yang harus menjadi perhatian khusus oleh Ombudsman adalah pada fungsi pencegahan dan Pemeriksaan Laporan karena dua fungsi ini yang menurut penilaian kurang efektif Sedangkan faktor yang menjadi hambatan Ombudsman Republik Indonesia Perwakilan Provinsi Sulawesi Barat dalam menjalankan perannya sebagai lembaga pengawasan dalam Pelaksanaan Tata Kelola Administrasi pada Pengadilan Negeri Mamuju adalah ada empat yaitu faktor regulasi, sumber daya manusia, faktor anggaran, faktor sosialisasi terhadap masyarakat.

\section{DAFTAR PUSTAKA}

Fachrudin, Irfan. 2004. Pengawasan Peradilan Administrasi Terhadap Tindakan Pemerintah, Alumni, Bandung.

Masthuri, Budhi. 2005. Mengenal Ombudsman Indonesia, PT. Pradnya Paramita, Jakarta.

Peraturan Mahkamah Agung Republik Indonesia Nomor 7 Tahun 2015 Tentang Organisasi dan Tata kerja Kepaniteraan dan Kesekretariatan Peradilan

Peraturan Ombudsman No. 30 Tahun 2018 Tentang Susunan Organisasi dan Tata Kerja Asisten Ombudsman Republik Indonesia

Peraturan Pemerintah Republik Indonesia No. 21 Tahun 2011 Tentang Pembentukan, Susunan, dan Tata Kerja Perwakilan Ombudsman Repubik Indonesia.

Surahman, Sujata Antonius. 2002. Ombudsman Indonesia di Tengah Ombudsman Internasional, Komisi Ombudsman Nasional, Jakarta.

Undang-undang Nomor 25 tahun 2009 tentang Pelayanan Publik.

Undang-Undang Nomor 37 Tahun 2008 tentang Ombudsman Republik Indonesia 